\title{
Kayıtdışı Ekonominin Bir Değerlendirmesi Ve Türkiye
}

\section{An Assessment Of Underground Economy And Turkey}

\author{
Cuma BOZKURT* \\ Gaziantep Üniversitesi
}

\begin{abstract}
Özet
Hem gelişmiş ülkeler de hem de gelişmekte olan ülkelerde resmi olmayan bir ekonomik yapı durumundaki yer altı ekonomisi dediğimiz kavram zaman içerisinde oldukça genişlemiş ve bir sektör ve belki de ayrı bir ekonomi haline gelmiştir. Durum böyle olunca bu ekonomilerin boyutunun ve etki alanlarının belirlenmesi ya da ölçümünün yapılması önem kazanmaya başlamıştır. Bu ekonomilerin sebep olduğu vergi kayıpları kadar ekonomik ve sosyal büyümeye etkileri de önemli bir sorundur. Özellikle bu durum konumu itibariyle geçiş yolları üzerinde bulunan ülkemiz öznelinde ayrı bir önem arz etmektedir. Bu konuyla ilgili olarak ekonomistler farklı ekonometrik tahminler önermişlerdir. Bu çalışmada bu etkilerin ve kayıpların tanımlanması, boyutu, ölçüm süreci ve teknikleri incelenerek Türkiye ekonomisi için birtakım öneriler ortaya konmaktadır.

Anahtar Kelimeler: Kayıtdışı Ekonomi, İllegal Yöntemler, Türkiye, Öneriler.
\end{abstract}

\begin{abstract}
In developed countries and in developing countries, we called as concept of underground economy which an unofficial state economic structure, greatly extended over time and become a sector and perhaps a separate economy. In that case, determination of dimension and domain or measurment of this economics which began important. Tax losses which caused by this economics and effects to economic and social growth as an important problem. Particularly this situation in the subjective of our country where located on transition roads by location is showing a separate importance. With regard to this subject economists have proposed various econometric estimates. In this paper, identification of these effects and losses, size, measurment process and its techniques are examined and for Turkish Economy is some suggestions are put forward.

Keywords: Underground Economics, Illegal Methods, Turkey, Suggestions.
\end{abstract}

\footnotetext{
* Yrd.Doç.Dr., Gaziantep Üniversitesi, İktisadi ve İdari Bilimler Fakültesi, İktisat Bölümü, email: cbozkurt@gantep.edu.tr
} 


\section{Giriş}

Gelişmekte olan ülkelerde gözlenen ekonomik büyüme yeterli istihdam imkânları yaratamayabilir ve işsizliğin azaltılmasına katkıda bulunamayabilir ve bu da kayıtdışı ekonominin ortaya çıkmasına zemin hazırlayabilir. Ancak kayıtdışı ekonomi artık hem geliş̧miş hem de gelişmekte olan ülkeleri yakından ilgilendiren bir olgudur. Kayıtdışı ekonomi adından da anlaşılacağı üzere en basit haliyle kayıt altına alınmamış faaliyetlerden oluşmaktadır. Yer altı ekonomisi, gizli ekonomi, kayıtsız ekonomi ve gölge ekonomisi gibi terimlerle de isimlendirilen kayıtdışı ekonomi günümüz dünyasında ve ülkemizde de oldukça önemli boyutlara ulaşmış durumdadır. Evde üretim gibi piyasa dışı ekonomik faaliyetlerden oluşabileceği gibi illegal ekonomik faaliyetlerden de oluşabilir ve insanlar, vergi ve sosyal güvenlik primlerindeki ağır yüklerden kaçınarak kayıtdışılığa yönelebilirler. Yüksek bir oranda seyreden vergi oranları ve sosyal güvenlik primleri, erken emeklilik ve işsizlik gibi faktörler kayıtdışılığa yönelişi arttırmaktadır. Yıllar boyu yüksek enflasyon süreçleri ve bununla beraber yaşamış olduğumuz ulusal ve küresel krizlerin de kayıtdışılığa yönelişteki payı inkâr edilemez. Bu yüzden kayıtdışı ekonominin sebeplerinin, etkilerinin ve sonuçlarının iyi analiz edilmesi gerekmektedir.

\section{Kayıtdışı Ekonomi ve Sebepleri}

Kayıtdışı ekonomi kavramının iktisatçılar tarafından incelenmeye ve tartışılmaya başlanmasının temelleri 1970'li yıllara kadar uzanmaktadır. 1970'li yılların sonlarında yayımlanan birkaç makale ile ekonomistlerin ilgisini çekmeye başlayan kayıtdışı ekonomi kavramı literatürde gayri resmi, enformel, düzensiz, ikinci, yeraltı, yasadışı, görünmeyen, kayıtlı olmayan, gölge ekonomi gibi farklı isimler taşımaktadır. Farklı açılardan ele alındığında farklı isimlerle adlandırılan kayıtdışı ekonomi kavramının birçok dilde en çok rastlanan ismi kara (black) ekonomidir(Akalın ve Kesikoğlu, 2007: 72).

Kayıt dışı ekonomiye ilgi II. Dünya savaşı sonrasında başlamış, Fransa'da ilki 1936 'da sonraki 1940 yılında olmak üzere kayıt dışı istihdam konusunda yasal düzenlemeler yapılmış, ilk defa 1958 yılında Cagan tarafından A.B.D.'de kayıt dışı ekonominin hacmi ölçülmeye çalışılmışır. Konunun hala güncel olmasının nedeni ise, genellikle bir sorun olarak görülen olgunun ortadan kaldırılamamış olmasıdır. Kayıtdışı sektörün büyüklüğünün, başta işsizlik oranı, bölgeler arasında gelir farklılı̆ı, kişi başına düşen gelir ve hatta enflasyon olmak üzere bütün sosyoekonomik göstergelere etkileri olacağıdır. Kayıtdışı ekonominin, kaynak dağılımında etkinlikten uzaklaşma ve gelir dağıımını bozucu etkileri nedeniyle ekonomide yarattığı refah kaybı, rekabette eşitliği bozması gibi ile devletin varlığına olan kamu güvenini sarsması diğer olumsuzlukları arasında sayılabilir. Kayıtdışı ekonominin en önemli olumsuzluklarından biri de vergi kaybı yaratmasıdır (Yurdakul, 2008: 206).

Kayıt dışı ekonomi literatürde yer altı ekonomisi, ikinci, paralel, resmi olmayan, kara ve düzensiz ekonomi olarak da adlandırımaktadır. Farklı adlara sahip iken yer altı ekonomisinin tanımı ve ölçüm yaklaşımı üzerinde bir görüş birliği yoktur. $\mathrm{Bu}$ nedenle yer altı ekonomisi ve ölçüm yaklaşımları için çok sayıda tanım mevcuttur(Öğünç ve Yılmaz, 2000: 1). Kayıtdışı ekonomi, "ya hiç belgeye bağlanmayarak ya da içeriği gerçeği yansıtmayan belgelerle, gerçekleştirilen ekonomik olayın(alım-satım), devletten ve işletme ile ilgili öteki 
kişilerden(ortaklardan, alacaklılardan, kazanca katılan işçilerden vb.) tamamen ya da kısmen gizlenerek, kayıtlı(resmi) ekonominin dışına taşmasıdır"(Altuğ, 1999: 257).

Kayıtdışı ekonomi, genel olarak, kamu otoritelerinin denetimi dışında kalan her türlü ekonomik işlem olarak tanımlanmaktadır. Kayıtdışı ekonominin kapsamı içine hem yasalarla yasaklanmış ekonomik faaliyetler, hem de yasalarla yasaklanmadığı halde bilinçli olarak kayıtlara geçirilmeyen, belgelendirilmeyen ekonomik faaliyetler girmektedir(Tepav, 2006: 68). Araştırmacılar tarafından resmi olmayan ekonomi anlamına gelen çeşitli terimler kullanılmışıı: Düzensiz ekonomi(Ferman ve Ferman,1973), yer altı ekonomisi(Gutmann,1977), kara ekonomi(Dilnot ve Morris.1981), gölge ekonomisi(Frey, Weck ve Pommerehne,1982, Cassel ve Cichy,1986) ve resmi olmayan ekonomi(McCrohan ve Smith,1986) terimleri kullanılmışır. Popüler medya ise; görünmez, saklı, batık, gölge, düzensiz, resmi olmayan, kayıtsız veya gizli terimlerini kullanmaktadır(Losby vd, 2002: 2). Aslında ekonomik aktivitelerin herhangi bir şekilde kaydedilmemesi kayıtdışı̆ı̆ı göstermektedir.

Belirli faaliyetler, hem ekonomik alanda üretken, hem de tamamen yasal olduğu halde çeşitli nedenlerle kamu otoritelerinden saklanmaktadır. Buradaki amaç; gelir, katma değer ve diğer vergilerden, sosyal güvenlik katkılarını ödemekten, kanunla belirlenmiş yasal düzenlemelerden (asgari ücret, güvenlik standartları vb.) kaçınma şeklinde özetlenebilir. Ülkemizde vergisel açıdan kayıtdışı ekonomik faaliyetler, vergi dairesinde mükellefiyet kaydı bulunmayanlar yada vergi mükellefiyet kaydı bulunduğu halde, gerçekleştirdikleri işlemleri gerçek vekille kayıtlara yansıtmayanlar tarafından yürütülmektedir. Esnafın vergi dairesine kayıt yaptırmadan marangozluk, terzilik benzeri işler yapması, tüccarın fatura düzenlemeden mal satması, tüketicinin alışverişte belge almaması, sanayicinin ürettiği ürünleri belgesiz satması, işverenin daha yüksek ücret alan işçisinin ücretini asgari ücret olarak Sosyal Sigortalar Kurumu'na bildirmesi, doktorun hastadan aldığı ücret karşılığında belge vermemesi gibi işlemler kayıtdışı ekonomiyi oluşturmaktadır(Tepav, 2006: 68).

Gölge ekonomisi veya yer altı ekonomisi olarak da adlandırılan kayıtdışı ekonomi dünyanın her tarafında yaygın bir şekilde görülmektedir ve artış gösterdiğine dair önemli işaretler vardır. Çoğu toplumlar bu faaliyetleri, resmi ekonominin dinamiklerini geliştirebilen vergi ve sosyal güvenlik sistemiyle ilgili reformlardan ziyade çeşitlilik arz eden çok sert önlemler veya eğitim vasıtasıyla kontrol etmeye çaba göstermektedirler. Kayıtdışı ekonomik faaliyetleri hakkında bilgi toplamak oldukça zordur. Etkili ekonomik politika kararları için, kayıtdışı ekonomide bir ülkenin kaynaklarındaki dağılım hakkında doğru istatistikleri elde etmek önemlidir. Politika yapıcıların özellikle kayıtdışı ekonominin yükselişiyle ilgilenmelerinin birkaç önemli nedeni vardır. Bunlar genel olarak şunlardır(Schneider ve Enste, 2000: 77-78);

- Büyüyen bir kayıtdışı ekonomi devlet tarafından fazla yüklenilen bireylerin reaksiyonu olarak görülebilir (Albert O. Hirschman 1970). Eğer kayıtdışı ekonominin artışı vergi ve sosyal güvenlik yüklerindeki bir artı̧̧ vasıtasıyla olmuşsa, kayıtdışı ekonomiye kaçışlar vergi ve sosyal güvenlik tabanını aşındırabilir (Mancur Olson 1982).

- İlerlemiş bir kayıtdışı ekonomi politikacılar için bazı zorluklara neden olabilir. Çünkü resmi göstergeler(-işsizlik, emek gücü, gelir ve 
tüketim üzerindeki-)güvenilir olmaz. Hatalı resmi göstergelere dayanan politikanın etkisiz veya daha kötü olması muhtemeldir.

- Büyüyen bir kayıtdışı ekonominin etkileri mutlaka göz önüne alınmalıdır. İlerlemiş bir kayıtdışı ekonomi bir yandan işçileri (yerli ve yabancı) resmi ekonomiden çekebilir. Öte yandan kayıtdışı ekonomide kazanılan gelirin bir kısmı resmi ekonomide harcanabilir. Böyle bir etki olumsuz mudur?

Ekonomik literatürde kayıt dışı ekonominin artan vergi yükü ve sosyal güvenlik payları, resmi ekonomide özellikle emek piyasalarında artan düzenlemeler, haftalık çalışma saatlerinde azaltmaların zorlaştırılması, vergi moralinin düşmesi ve erken emeklilik gibi çok önemli nedenleri vardır. Vergi yükünün ve sosyal güvenlik paylarının artışı artan yer altı ekonomik faaliyetlerinin arkasındaki en önemli faktördür. Bilindiği gibi vergiler ekonomik ajanların emek-boş zaman seçimlerini etkiler ve aynı zamanda emek arzını yeraltına veya ekonominin vergi dışı sektörlerine doğru harekete geçirir. Resmi ekonomide işverenler için toplam emek maliyeti ve emeğin vergi kazancı arasındaki farklılık arttığı zaman yer altı ekonomik faaliyetlerinin artması beklenmektedir. Bu iki konu arasındaki farklılık toplam vergi yükünü gösterir ve bu nedenle sosyal güvenlik sistemine bağlıdır. Yüksek vergi ve sosyal güvenlik payları işverenler için daha düşük vergi geliri ortaya çıkarabilir ve bu yüzden bu işverenleri daha düşük ücret oranlarından kaçınacakları yer altı ekonomisinde çalışmaya teşvik eder(Öğünç ve Yılmaz, 2000: 3).

Kayıt dışı ekonominin ortaya çıkmasının pek çok nedeni bulunmaktadır. Vergi, nihayetinde bireylerin gelir ve servetinde bir azalma neticesi doğurduğundan bireyler vergi ödemekten o kadar hoşlanmazlar. Eğer vergi denetimleri etkin değilse, vergi kaçırmak kolay ve cezası ağır değilse bazı bireyler vergi kaçakçılığına yönelebilirler. Yine alış ve satışların, defter ve belgelere intikali bazı işlemlerde ya da faaliyetlerde kolayca gizlenebilir ya da eksik olarak kaydedilebilir. Özellikle hizmet sektöründe tüm faaliyetlerin ve işlemlerin hesaplara kaydedilmemesi mümkündür. Denetimler ancak çok yoğun ve etkin olduğu takdirde bu sektördeki vergi kaçakçllı̆ı azaltılabilir. Sürekli fiyat artışları, işletmeleri zor durumda bırakır ve bunun neticesinde bazı işletme sahipleri vergilerini eksik beyan edilen matrahlar üzerinden ödeme eğiliminde olabilirler(Aktan, 1999: 2). Devletin asli görevlerinden olan vergi toplama ne yazık ki devleti mükelleflerin gözünde sevimsiz yapmaktadır. Yıllardır süregelen ve son yıllarda düşüş gösteren yüksek enflasyon oranlarıyla birlikte enflasyonun ekonomik ve sosyal maliyetleri de mükelleflerin gelirlerini saklamalarına ve eksik beyanda bulunmalarına neden olmaktadır.

Kayıtdışı ekonominin, mali, ekonomik, politik, sosyal, psikolojik ve hukuki birçok sebebi bulunmaktadır. Bu çerçevede, ülkenin ekonomik sistemi ve yapısal özelliklerinin kayıtdışılı̆ı oluşturmada rol oynadığı görülmektedir. Özellikle, istihdam açısından bakıldığında, ekonomide küçük işletmelerin yaygınlığı ile tarım ve hizmetler sektörüne dayalı faaliyetlerin ağılıkta olması kayıtdışılığa yol açan önemli etkenlerdir. Ekonominin azgelişmişliği, yüksek enflasyon, ekonomi politikaları, istikrarsızlık, krizler, kayıtlı ekonomide istihdam ve gelir imkânlarının kısıtlı ve yüksek maliyetli olması, kayıtdışılığı etkileyen unsurlar olarak karşımıza çıkmaktadır(Us, 2004: 10).

Kuşkusuz kayıtdışı ekonominin, ekonomik nedenlerinin yanı sıra sosyolojik nedenleri de vardır. Örneğin, hızlı nüfus artışı ve göçün doğurduğu işsizlik ve çarpık kentleşme işgücü piyasasını olumsuz etkilemekte ve bu durum kayıtdışı istihdama 
ortam hazırlamaktadır. Kentleşme ve nüfus artış hızları dikkate alındığında, metropol niteliği kazanan yerleşme merkezlerinde ortaya çıkan sorunlar giderek ağılaşmakta, bu durum yeni değer yargılarının oluşmasına ve yasalara itaat eğiliminin azalmasına yol açmaktadır. Ayrıca ülkenin eğitim düzeyinin düşüklüğü vergi bilincinin geliştirilip yaygınlaştırlamamasına, vergi ve diğer yasal yükümlülüklerin gerektiği gibi yerine getirilememesine neden olmaktadır(DPT, 2001: 1).

Ekonomik sebeplere ek olarak, hızlı nüfus artışı, köyden kente göç ile birlikte oluşan işsizlik ve çarpık kentleşmenin, işgücü piyasasında olumsuzluklara yol açarken kayıtdışı istihdama da zemin hazırlamakta olduğu belirtilmektedir. Özellikle, yüksek işsizlik oranının söz konusu olduğu durumlarda, kayıtdışı ekonomiye giriş ve çıkışların daha az maliyette gerçekleşeceği varsayımı altında, kayıtdışı istihdamda büyüme olması muhtemeldir. Buna ek olarak, kişi başına harcanabilir geliri düşük olan ülkelerde, kayıtlı bir işten elde edilen gelir belirli bir yaşam düzeyi için yeterli olmamakta; ikinci bir işte çalışma ise kayııtışı kalmaktadır(Us, 2004: 10).

Kayıtdışı ekonominin ortaya çıkmasında en temel sebeplerden biri, insan intiyaçlarının sonsuz fakat kaynakların sınırlı olması gerçeğidir. İnsan, daha iyi bir hayat şartını sağlayabilmek yani daha çok gelir ve servete sahip olmak ve harcama yapabilmek için kazancını devletle paylaşmayı arzu etmez. Bunun yanında iktisadi faaliyetlerini kayıt dışında sürdüren bir kişi, alıştı̆ı tüketim düzeyinden daha düşük bir tüketim düzeyine geçmek istemeyecektir. Dolayısıyla sorunların temelinde insanların kendi faydalarını maksimize etme isteği yatmaktadır(Baldemir vd, 2010: 3).

\section{Kayıtdışı Ekonominin Sınıflandırılması}

Kayıtdışı ekonomik faaliyetleri dört ana kategori altında gruplandırılabilir(Sennholz, 2003: 4):

- Vergi otoritelerine rapor edilmeyen gelir getirici ekonomik faaliyetler.

- Zorunlu hükümet lisansları, emek kanunları, tarımla ilgili hükümet düzenlemeleri, ihracat ve ithalat kontrolleri, para ve bankacllık üzerindeki hükümet kontrolleri, enerji üretimi ve dağıtımı ile ilgili hükümet kontrolleri vb. kurallara uymadan yapılan ekonomik üretimler. Kurallara uymayanlar vergilerden kaçabilir veya kaçmayabilir, ama onların hepsi illegal bir şekilde çalışır.

- Sosyal güvenlik yardımı ya da kamu yardımı alan kar sahiplerinin transferleri vasıtasıyla üretim faaliyeti. Onların çalışma özgürlüğü katı bir şekilde kısıtlanmıştır.

- İkamet statüleri olmaksızın yabancılar tarafından gerçekleştirilen illegal ekonomik faaliyetler. Onlar gelir vergisi ve diğer vergileri ödeyebilirler ama sınır dışı edilme korkusuyla kayıtdışında kalmalıdırlar.

Literatürde kayıtdışı ekonomi ile ilgili pek çok isim kullanılmaktadır. Bunlar: yer altı, gizli, gri, gölge, enformel, gizli kapaklı, illegal, gözden kaçmış, rapor edilmemiş, kayıt edilmemiş, ikinci, paralel ve kara(Feige, 1990).

Genel olarak dört tür spesifik kayıtdışı ekonomi ayrımı yapılmaktadır(Feige, 1990);

- İllegal ekonomi

- Rapor edilmeyen ekonomi

- Kayit edilmeyen ekonomi 


\section{İllegal Ekonomi}

- Enformel ekonomi

İllegal ekonomi, yasal ticaret şekillerinin faaliyet alanını tanımlayan legal durumlara uyulmadan izlenen ekonomik faaliyetlerden kaynaklanan gelirden oluşur. İllegal ekonomiye katılan kişiler yasaklanan mal ve hizmetlerin üretimi ve dağıtımı ile uğraşırlar.

\section{Rapor Edilmeyen Ekonomi}

Rapor edilmeyen ekonomi, vergi yasasındaki kodlamalar gibi kurumsal olarak oluşturulan mali kurallardan kaçmak veya kaçınmaktan kaynaklanan ekonomik faaliyetlerden oluşur. Rapor edilmeyen ekonominin özeti, vergi otoritesine rapor edilmesi gereken fakat rapor edilmeyen gelirin miktarıdır.

\section{Kayıt Edilmeyen Ekonomi}

Kayıt edilmeyen ekonomi, istatistiksel devlet kurumlarının rapor gereksinimlerini tanımlayan kurumsal kurallardan kaçınmaktan kaynaklanan ekonomik faaliyetlerden oluşur. Özetle, mevcut kurallar ve sözleşmeler altında milli hesaplama sistemlerine kayit edilmesi gereken fakat kayıt edilmeyen gelirin miktarıdır.

\section{Enformel Ekonomi}

Enformel ekonomi, hükümet lisansları, emek sözleşmeleri, finansal krediler ve sosyal güvenlik sistemlerinin maliyetlerinden kaynaklanan ekonomik faaliyetlerden kaçınmaktan oluşmaktadır.

\section{Kayıtdışı Ekonomiyi Ölçüm Yöntemleri}

Kayıtdışı ekonomiyi ölçme teşebbüsleri ilk olarak onu tanımlama problemiyle yüz yüze gelir. Çalışmalarda yaygın olarak kullanılan bir tanım şöyledir: resmi olarak hesaplanan (veya gözlemlenen) Gayrisafi Milli Hasıla (GSMH)'ya katılan ama şu anda kayıtdışı olan tüm ekonomik faaliyetlerdir. Örneğin bu tanım Edgar L. Feige(1989,1994), Schneider(1994a), Frey ve Werner Pommerehne(1984) ve Herald Lubell(1991)'de kullanılmıştır.(Schneider ve Enste,2000,s.78) GSMH anlamındaki kayıtdışı ekonomi; tanım olarak GSMH hesapları içinde olmasına rağmen kapsanamayan üretim ve gelirlerin büyüklüğünü, vergi açısından; vergilenmesi gerektiği halde, çeşitli sebeplerle vergi yetkililerinden gizlenen ve denetlenemeyen gelirleri, istihdam açısından; sosyal güvenlik kurumlarına kayıtlı olmadan çalışan kesimleri ve toplam istihdam kayıtlarında gözükmeyen ve işsiz olduğu kabul edilen eksiklikleri ifade etmektedir. "Kayıtdışı ekonomi" deyimi ülkemizde bütün bu alanları kavrayacak bir deyim olarak kullanılmaktadır.(Ilgın, 2002: 145-146) Tablo 1 de kayıtdışı faaliyetlerin sınıflandırılması verilmektedir (Schneider ve Enste, 2000: 79).

Tablo 1: Kayıtdışı Ekonomik Faaliyetlerin Sınıflandırılması

\begin{tabular}{|c|c|c|c|c|}
\hline Faaliyetler & \multicolumn{2}{|c|}{ Parasal İşlemler } & \multicolumn{2}{|c|}{ Parasal Olmayan İşlemler } \\
\hline $\begin{array}{c}\text { İllegal } \\
\text { Faaliyetler }\end{array}$ & $\begin{array}{r}\text { Çalıntı mallar } \\
\text { Uyuşturucu m } \\
\text { ve imalatı, } \\
\text { Kumar, Kaç } \\
\text { Dolandı }\end{array}$ & $\begin{array}{l}\text { ticaret, } \\
\text { dde işleri } \\
\text { hişelik, } \\
\text { çllık ve } \\
\text { ulık }\end{array}$ & $\begin{array}{r}\text { Takas; uyuştı } \\
\text { mallar, kaçaks } \\
\text { kullanımı için } \\
\text { üretmek, kendi } \\
\text { hırsızık }\end{array}$ & $\begin{array}{l}\text { l, çalıntı } \\
\text { b. Kendi } \\
\text { sturucu } \\
\text { anımı için } \\
\text { lak }\end{array}$ \\
\hline $\begin{array}{c}\text { Legal } \\
\text { Faaliyetler }\end{array}$ & Vergi Kaçırma & $\begin{array}{l}\text { Vergiden } \\
\text { Kaçınma }\end{array}$ & Vergi Kaçırma & $\begin{array}{l}\text { Vergiden } \\
\text { Kaçınma }\end{array}$ \\
\hline
\end{tabular}




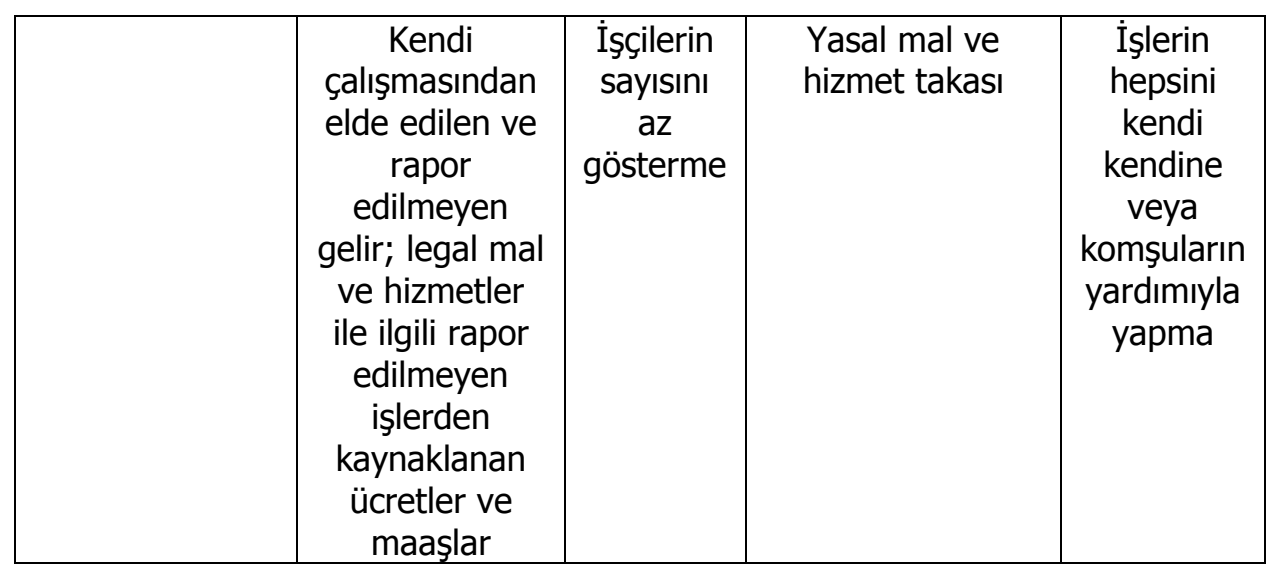

Kaynak: Schneider ve Enste, 2000.

Kayıtdışı ekonominin kayıtlı ekonomiye nispetle büyüklüğünü tespit etmek amacıyla bazı yöntemler geliştirilmiştir. Birçok varsayıma dayalı olarak yapılan bu çalışmaların bir ölçümden ziyade "tahmin çalışması" olduğunu, farklı yöntemlerle, hatta aynı yöntemle yapılsa bile farklı varsayımlarla çok farklı sonuçlara ulaşılabileceğini belirmek gerekmektedir. Her yöntem kayıtdışılığa farklı bir açıdan yaklaşmakta ve kapsama alanları farklı olabilmektedir. Bu açıdan, tahmin çalışmaları yapılırken, kapsamın iyi belirtilmesi, varsayımların mümkün olduğunca gerçekçi yapılması, ulaşılan sonuçların diğer bulgularla tutarlılığının sınanması ve muhtemel hataların belirtilmesi gerekmektedir. Tahmin yöntemleriyle; kayıtdışı ekonominin mutlak ve nispi büyüklüğünün, zaman içinde büyüme hızının, yol açtığı vergi ve sosyal güvenlik prim kayıplarının ne kadar olduğu gibi sorulara cevap aranmaktadır(Ilgın, 2002: 146).

Kayıtdışı ekonominin doğası onun doğrudan ölçümüne engel olduğu için araştırmacıları bazı tahmin yöntemleri kullanmaya zorlamaktadır. Kayıtdışı ekonomiyi hesaplamak için kullanılan çok sayıda tahmin yöntemi bulunmaktadır. Bu hesaplamalar ülkeden ülkeye ve kullanılan yönteme göre çok büyük farklılıklar gösterir(Çetintaş ve Vergil, 2003: 20).

Kayıtdışı ekonominin büyüklüğünün ölçümüyle ilgili olarak temelde üç önemli yaklaşım söz konusu olmaktadır. Bunlar; doğrudan yaklaşımlar, dolaylı yaklaşımlar ve model yaklaşımıdır.

Doğrudan Yaklaşımlar: Bunlar ya gözlemleri ve gönüllü cevaplara dayanan örnekleri ya da vergi denetimi ve diğer rızaya bağlı metotları kullanan mikro yaklaşımlardır. Örnek gözlemler kayıtdışı ekonomiyi ölçmede ülkelerin bir kısmında yaygın bir şekilde kullanılmaktadır. Bu metodun ana avantajı kayıtdışı ekonominin yapısı hakkında detaylı bilginin elde edilebilmesidir.(Schneider ve Enste, 2000: 91) Seçilen bir alanda ve sınırlı bir örnekten hareketle yapılan bu çalışmalardan elde edilen sonuçlar birleştirilerek seçilen işkolundaki veya farklı işkollarındaki araştırmalarla birleştirilerek ülkenin bütünündeki kayıtdışlığın boyutu ortaya konulmaya çalışılmaktadır.(Ilgın, 2002: 147). Yöntemin esası, anket çalışmasıyla kayıtdışı ekonominin tahmin edilmesidir. Bu yaklaşımla kayıtdışı ekonomi konusunda ayrıntılı bilgi alınabilmekte ve bu faaliyetlerin yapısal özellikleri tespit edilebilmektedir(Şimşek vd., 1994: 11). Doğrudan yaklaşımlar iki çeşittir: vergi iadelerinin denetimi ve anket haritası(Anno, 2003: 5). 
Kayıtdışı ekonomiye girme kararı ile ilgili sosyo-ekonomik motivasyonlar ve kayıtdışı ekonominin yapısı hakkındaki detaylı bilgiyi sağlama yeteneğinden dolayı mikro anketler problemin doğasını anlamak için potansiyel olarak güçlü bir fırsattır(Eilat ve Zinnes, 2000: 18). Metot, gelir açığının derecesinin belirlenmesinde ve maliyet etkili bir vergi uyum programının düzenlenmesinde faydalı olabilir. Ama bu metot kayıtsız ekonomik birimlerin faaliyetlerini ortaya çıkarmayabilir. Etkili bir vergi yönetiminin eksikliği bu metodun daha az etkili olması eğilimini gösterecektir. Sonuç olarak bu metot kayıtdışı ekonominin büyüklüğünü ortaya koymada yetersiz olabilir(Eilat ve Zinnes, 2000: 18).

Dolaylı Yaklaşımlar: Bu yaklaşım aynı zamanda gösterge yaklaşımı olarak da adlandırımaktadır. Makroekonomik bir yapı arz etmektedir ve kayıtdışı ekonominin zaman içerisindeki gelişimi hakkında bilgleri de içeren çeşitli ekonomik ve diğer göstergeleri kullanmaktadır(Schneider ve Enste, 2000: 92). Bu yöntemlere dolaylı denilmesinin sebebi, başka amaçlar için hazırlanan milli muhasebe hesapları, parasal büyüklükler, demografik göstergeler, vergi istatistikleri gibi verilerin ve bu verilerdeki gelişmelerin analiz edilmesi esasına dayalı olmalarındandır(Ilgın, 2002: 147). Doğrudan metotlar kayıtdışı faaliyetlerdeki dolaylı sinyallerden ziyade kayıtdışında çalışan ekonomik aktörleri doğrudan ortaya çıkaran metotlardır. Dolaylı metotlar ise genellikle toplam ekonomik faaliyetleri ölçmeye çalışır ve bu nedenle zaman içerisinde kayıtdışı ekonominin büyüklüğündeki trendlerin belirlenmesine de yardımcı olurlar(Eilat ve Zinnes, 2000: 18). Dolaylı metot beş kategoride ele alınabilir: ulusal harcama ve gelir istatistikleri arasındaki uyuşmazlık, emek gücünün resmi ve gerçek istatistikleri arasındaki uyuşmazlık, işlem yaklaşımı, para talebi veya nakit-mevduat oranı yaklaşımı ve fiziksel çıktı metodu(Anno, 2003: 5).

Bununla birlikte kayıtdışı üretim aşağıdaki nedenlerden dolayı direkt olarak gözlemlenmeyen üretim faaliyetleri alanını gösterir(Anno, 2003: 4):

- Ekonomik nedenler(kasıtlı olarak vergiden kaçınma isteği, işçilerin lehine sosyal yardım veya aynı zamanda asgari ücretle, çalışma saatleri ve iş güvenliği ile ilgili kanun hükümlerini gözlemlemeden kaçınmak vb.)

- İstatistiksel nedenler(duyarlılık eksikliğinden dolayı idari formları ve istatistiksel anketleri doldurmadaki başarısızlık, hızla gelişen üretim sitemindeki değişiklikleri anlamada ortaya çıkan zorluklar)

Model Yaklaşımı: Model yaklaşımı kayıtdışı ekonomiyle ilgili açık bir şekilde çoklu nedenler ve aynı zamanda çoklu etkiler varsayımı yapar(Schneider ve Enste, 2000: 97). Bu metot kayıtdışı ekonominin sebepleri ve etkileri üzerine odaklanır(Frey ve Schneider, 2000: 5). Model yaklaşımı, gizli ekonominin birkaç göstergesi ve birkaç nedenden dolayı gizli değişkenlerin istatistiksel teorisine dayanır(Anno, 2003: 5). Model Metodu: Bu metot kayıtdışı ekonomik faaliyetlerin varlığını yakalayan birkaç göstergeyi(etkiler) kullanma avantajına sahiptir(Eilat ve Zinnes, 2000: 21). Bu yaklaşımın öncüleri çeşitli yıllar için yirmidört OECD ülkesine yatay kesit analizini uygulayan Weck(1983), Frey ve Weck(1983a,b), Frey ve WeckHannemann(1984)'dir.

Kayıt dışı ekonomi kavramı çoğu kez vergilendirmeden kaçan işlemleri ifade etmek için kullanılmaktadır. Kayıt dışı ekonomi kavramının vergilemeden kaçan işlemleri ifade etmek için kullanılması, resmi GSMH tahminlerinin gelir vergisi beyannamelerinde bildirilen gelirden hareketle yapılması durumunda anlamlı olur. Bu durumda vergilendirmeden kaçan ekonomik faaliyetler ve bu faaliyetlerin doğurduğu 
gelir, gelir vergisi beyannamelerinde yer almayacağından GSMH tahminlerine yansımaz ve kayıt dışı ekonomi beyan edilmeyen gelir miktarına eşit olur(Candan, 2007: 4).

Kayıtsız milli gelirin tahminine yönelik ilk teşebbüs Kaldor(1956) tarafından yapılmışıı. Kaldor(1956) Hindistan'da gelir vergisinden kaçınılan gelirin tahminini yapmıştır. Ama 1970 'lerin sonunda ve 1980 'lerin başlarında Avrupa ve Amerika'da kayıtsız milli gelirin yani saklı veya gizli ekonominin tahminine yönelik biraz da olsa çabalar vardır. Bu tahminler, kayıtdışı ekonominin boyutunu tahmin edip vurgulamış ancak tahminlerin standart hataları gibi diğer temel bilgileri ortaya koymamıştır. Pissarides ve Weber(1989) ve Bhattacharyya(1990), kayıtdışı ekonomi tahminlerinin standart hatalarını ortaya koymaya çalışmışır. Tahmin metotlarının genel bir taslağı Bhattacharyya(1990) ve Bhattacharyya ve Ghose(1998)'de ortaya konmuştur. Bu ilk olarak kayıtdışı ekonominin açık bir şekilde tahminini gösterecektir. İkinci olarak bu yaklaşım aynı zamanda kayıtdışı ekonomi için ayrışıııımış tahminleri elde etmemizi sağlayacaktır. Bir ekonomik faaliyet varsayımı altında $M$ tüm sektörlerde/bölgelerde veya endüstrilerde gerekli ${ }^{*}$,ve $M$ faaliyetinin seviyesi $k$ sektörüyle bağlantılı gelir ve diğer değişkenler tarafından belirlenir. Böylece ' $t$ ' zamanında;

$$
M_{t}=M_{1 t}+M_{2 t}+M_{k t} \text {. }
$$

Bu varsayım ile;

$$
M_{j t}=f_{j}\left(Y_{j t}, Y_{j h t}, Z_{j t}\right) \quad j=1, \ldots, k .
$$

Burada, $Y_{j t}$ jninci sektördeki kayıtlı gelir/üretim, $Y_{j h t}$ jninci sektördeki kayıtsız gelir/üretim ve $Z_{j t} \quad M_{j t}{ }^{\prime}$ yi belirleyen değişkenlerin bir vektörüdür(Bhattacharyya, 1999: 349).

\section{Kayıtdışı Ekonominin Etkileri}

Kayıtdışı ekonominin en belirgin negatif etkisi ekonomik politikaları oluşturma sürecinde görülür. Geniş hacimde bir kayıtdışı ekonomi, işsizlik, milli gelir vb. resmi makroekonomik büyüklükleri çarpıtarak, bu verilerin güvenilirliğini azaltır. Bu verilerden yola çıkılarak oluşturulan ekonomik politikaların etkinliğini sınırlayabilir ya da tamamen ortadan kaldırabilir. Çünkü yeterince etkin parasal ve mali politikalar oluşturabilmek için üretim ve istihdam gibi anahtar istatistiklerde belirli bir kesinliğin olması şarttır(Çetintaş ve Vergil, 2003: 20).

Kayıtdışı ekonomi sosyal güvenlik kurumlarının finansal pozisyonlarını zarara uğratabilir. Kayıtsız firmalar sosyal güvenlik katkılarını ödemezler. Kayıtdışı ekonomi aynı zamanda hükümetin vergi gelirini düşürür ve düşen vergi geliri hükümetin düşük gelirli insanlara sosyal transferlerini sınırlar. Sosyal transferlerin sınırlanması düşük gelirli insanlar için daha zorlu yaşam standartlarına neden olabilir ve toplumdaki sosyal tansiyonu arttırabilir(Öğünç ve Yılmaz, 2000: 5-6).

Öte yandan, kayıtdışı ekonominin en önemli olumsuz etkilerinden birinin, devletin temel gelir kaynağı olan vergi gelirlerini azaltması olduğunu söylemek mümkündür. Ekonomik faaliyetlerin kayıtdışı bırakılması, vergilerin eksik ya da hiç

${ }^{1} M$ için mevcut literatürde kullanılan ekonomik faaliyetler: (1) dolaşımdaki para(Bhattacharyya,1990); (2) bir hanehalkının toplam harcaması(Pissarides ve Weber,1989);

(3) enerji tüketimi(Gupta ve Mehta,1982). 
ödenmemesine neden olmakta ve devletin vergi gelirleri azalmaktadır. Vergi gelirlerinin azalması sebebiyle ise bütçe finansmanının sağlanması için borçlanma yoluna gidilmektedir. Borçlanma sonucunda ise faiz oranlarında yükseliş yaşanmakta; faizlerdeki artış yatırımları azaltarak, gerek milli geliri gerekse istihdamı olumsuz etkilemektedir. Bütçe açıklarının borçlanma yoluyla finansmanı sonucu artan faizler sebebiyle kamu borçlanma maliyetinde artış kaydedilmekte; dolayısıyla, bütçe açıkları giderek artmaktadır(Us, 2004: 13).

Toplanan vergilerin verimli alanlarda kullanılmaması, israfa varan kamu harcamaları, devlet kadrolarının popülist nedenlerle aşırı şişirilmesi gibi faktörler mükelleflerin devlete olan güvenini sarsmakta ve vergi ödememe yoluna gitmelerine ortam hazırlamaktadır(Işık ve Acar, 2003: 122).

Kayıtdışı ekonomi, resmi ekonomi üzerinde bazı pozitif etkilere de sahiptir. Bir ülke ekonomisinde istihdam ortaya çıkarır. Kayıtdışı ekonomiyi oluşturan firmalar kayıtlı firmalardan daha düşük maliyet yapısına sahip olurlar ve bu yüzden onların emek talebi resmi ekonomideki firmalardan daha yüksek olabilir. Ayrıca Kayıtdışı ekonominin bir sonucu olarak sosyal refah seviyesi artabilir. Firmalar mallarını ve hizmetlerini genel piyasa fiyatlarından daha düşük bir fiyatta satabilirler ve bu yüzden daha düşük fiyatlar toplumun satın alma gücünü arttırabilir ve halkın genel refah seviyesi artar(Öğünç ve Yılmaz, 2000: 6).

Kayıtdışı ekonomi bazen resmi ekonomi üzerinde pozitif etkilere sahip olabilir. Bazı araştırmacılar, kayıtdışı ekonominin büyümesi ile resmi ekonominin büyümesi arasında pozitif bir ilişki olduğunu düşünmektedir. Örneğin, Adam ve Ginsburg Belçika ekonomisi üzerine yapmış oldukları çalışmalarında, resmi bir ekonomi ile kayıtdışı ekonominin büyümesi arasında pozitif bir ilişkinin varlığını tespit etmiş̧ler ve belirli varsayımlar altında (örneğin kayıtdışı ekonomiye daha düşük giriş maliyetleri) genişletici bir mali politikanın hem kayıtlı, hem de kayıtdışı ekonominin her ikisinde de pozitif bir uyarıcılığa sahip olduğu sonucuna ulaşmışlardır(Çetintaş ve Vergil, 2003: 18-19).

Kayıtdışı ekonomiye yol açan güçleri anlamak onunla mücadele etmek için doğru politika reçetelerini bulunmasına yardım eder. Kayıtdışı ekonominin nedenleri konusunu anlamanın en iyi yolu ekonomik ajanların (bireyler veya firmalar) karşı karşıya kaldığı teşvikleri analiz etmektir. Bunun için resmi ekonominin dışına çıkarak kayıtdışı ekonominin faydalarını ve maliyetlerini tanımlamaya gereksinimimiz vardır. Literatürde söz edilen en baskın faktör vergi oranlarıdır. Yaygın tema, yüksek vergilerin(hem marjinal hem de toplam da) ekonomik ajanların kararları üzerinde negatif bir etkiye sahip olacağı şeklindedir(Eilat ve Zinnes, 2000: 14).

Kayıtdışı ekonominin önemi özellikle gelişmekte olan ülkelerde ve etkin piyasa faaliyetlerini desteklemek için yasal ve politik kurumların yeterli olmadığı geçiş ekonomilerinde ortaya çıkmaktadır. Bir ülkede resmi olmayan ekonominin büyüklüğünü tam olarak ölçmek zordur. Bununla birlikte bazı araştırmacılar gayri safi yurtiçi hâsılada resmi olmayan ekonominin payını dolaylı olarak tahmine çalışmışlar ve kayıtdışı ekonominin önemli bir boyutta olduğunu görmüşlerdir*(Choi and Marcel, 2005: 817). Gelişmekte Olan Ülkelerde, Geçiş Ülkelerinde ve OECD Ülkelerinde Kayıtdışı Ekonominin Ortalama Büyüklüğü Tablo 2 de sunulmuştur.

${ }^{2}$ Bakınız Schneider ve Enste,2000. 
Tablo 2. Gelişmekte Olan Ülkelerde, Geçiş Ülkelerinde ve OECD Ülkelerinde Kayıtdışı Ekonominin Ortalama Büyüklüğü(Gayri Safi Yurt İçi Hasılanın \%'si)

\begin{tabular}{|c|c|c|c|}
\hline Ülkeler/YIllar & $1992 /$ & $2000 /$ & $2002 /$ \\
\hline Afrika(Geliş̧mekte Olan) & 3000 & 2001 & 2003 \\
\hline Orta ve Güney Amerika(Gelişmekte Olan) & 34.2 & 37.4 & 41.2 \\
\hline Asya(Geliş̧mekte Olan) & 20.9 & 37.7 & 41.5 \\
\hline Geçiş Ülkeleri & 31.5 & 34.4 & 26.3 \\
\hline Yüksek Gelişme Gösteren OECD Ülkeleri & 13.2 & 15.7 & 37.9 \\
\hline Güney Pasifik Adası & 31.7 & 32.6 & 16.8 \\
\hline Komünist Ülkeler & 19.4 & 20.7 & 21.4 \\
\hline 145 Ülkenin Ortalaması & 33.6 & 34.5 & 35.2 \\
\hline
\end{tabular}

Kaynak: Schneider, 2004.

145 ülkenin ortalaması 1999-2003 yılları arasında yaklaşık olarak \% 33-35 arasında değişme gösterirken, gelişmekte olan Afrika ve Orta ve Güney Amerika ülkelerinde oran hep ortalamanın üzerinde seyretmiştir. Gelişmekte olan Asya ülkeleri ise ortalamanın altında bir kayıtdışıllı yüzdesine sahiptir. Komünist ülkelerin yüksek gelişme gösteren OECD ülkelerinden sonra en az kayıtdışlığın olduğu ülkeler olması ekonomik sistemlerle ilgili olarak yeni değerlendirmelerin yapılmasına intiyac olduğunu göstermektedir.

Gelir dağııımı açısından bakıldığında; gelir dağıımındaki adaletsizlik, düşük gelir grubunun genişliği ve orta gelir grubu üyelerinin nispi olarak azlığı kayıtdışı̆̆ı̆ı nedenleri arasındadır. İktisadi kriz ve durgunluk dönemleri de kayıtdışlığa uygun bir zemin oluşturmaktadır. Böyle dönemlerde işsiz kitleler, kayıtlı ekonomide bulamadıkları istihdam imkânlarını kayıtdışı faaliyetlerde arayabilmektedir. Müteşebbisler ise kriz ve durgunluğun etkilerini minimuma indirmek ve özellikle istihdam ve üretim açııından esnek davranabilmek gayesiyle kayıtdışı faaliyetlere yönelmektedirler(Işık ve Acar, 2003: 120). Çeşitli araştırmacıların değişik ülkelerde değişik yöntemlerle yapmış oldukları tahminler Tablo 3 de gösterilmektedir.

Tablo 3. Dünyada Kayıtdışı Ekonomi Tahminleri

\begin{tabular}{|c|c|c|c|c|}
\hline Ülke & Araştırmacı & YIl & Yöntem & Tahmin(\%) \\
\hline \multirow{4}{*}{ ABD } & Bhattacharyya & 1984 & Ekonometrik & 16.18 \\
\cline { 2 - 5 } & Tanzi & 1976 & Ekonometrik & $3.4-5.1$ \\
\cline { 2 - 5 } & Feige & 1979 & Nakit Oranı & 28.0 \\
\cline { 2 - 5 } & Gutmann & 1979 & Nakit Oranı & 16.5 \\
\cline { 2 - 5 } & Park & 1977 & Milli Gelir Farklılıkları & 4.0 \\
\cline { 2 - 5 } & $\begin{array}{c}\text { Schneider, Buehn } \\
\text { ve Montenegro }\end{array}$ & 2007 & Mimic & 9 \\
\hline \multirow{4}{*}{ Avustralya } & Kiregaessner & 1980 & Ekonometrik & $8.0-12.0$ \\
\cline { 2 - 5 } & Langfeldt & 1980 & Nakit Oranı & $4.0-13.0$ \\
\cline { 2 - 5 } & Petersen & 1974 & Milli Gelir Farkllıkları & 4.8 \\
\cline { 2 - 5 } & Norman & 1982 & Ekonometrik & 13.40 \\
\cline { 2 - 5 } & Tucker & 1979 & Nakit Oranı & 10.70 \\
\cline { 2 - 5 } & $\begin{array}{c}\text { Schneider, Buehn } \\
\text { ve Montenegro }\end{array}$ & 2007 & Mimic & 15 \\
\hline
\end{tabular}




\begin{tabular}{|c|c|c|c|c|}
\hline \multirow[b]{2}{*}{ Hollanda } & Broesterhuizen & 1979 & Duyarlılık Analizi & 4.8 \\
\hline & $\begin{array}{l}\text { Schneider, Buehn } \\
\text { ve Montenearo }\end{array}$ & 2007 & Mimic & 13.2 \\
\hline \multirow{5}{*}{ İngiltere } & Dilnot ve Morris & 1979 & Nakit Oranı & 7.2 \\
\hline & O'higgins & 1978 & Milli Gelir Farkılıkları & 2.9 \\
\hline & Feige & 1979 & İşlem Hacmi & 15 \\
\hline & Macafee & 1978 & Milli Gelir Farklılıkları & $2.5-3.0$ \\
\hline & $\begin{array}{l}\text { Schneider, Buehn } \\
\text { ve Montenegro }\end{array}$ & 2007 & Mimic & 13.2 \\
\hline \multirow[b]{2}{*}{ İtalya } & Gaetani-Darogana & 1980 & İstihdam & $10-20$ \\
\hline & $\begin{array}{l}\text { Schneider, Buehn } \\
\text { ve Montenegro }\end{array}$ & 2007 & Mimic & 27.4 \\
\hline \multirow{4}{*}{ İsveç } & Hansson & 1979 & Milli Gelir Farklılıkları & $3.9-6.5$ \\
\hline & Riskspolisstryrelse & 1977 & Vergi Yaklaşımı & $1.4-5.6$ \\
\hline & Klovland & 1978 & Ekonometrik & 13.2 \\
\hline & $\begin{array}{c}\text { Schneider, Buehn } \\
\text { ve Montenegro }\end{array}$ & 2007 & Mimic & 20.4 \\
\hline \multirow{2}{*}{ Cezayir } & Schneider & 2002 & $\begin{array}{l}\text { Mimic ve Döviz } \\
\text { Talebi } \\
\end{array}$ & 35.6 \\
\hline & $\begin{array}{l}\text { Schneider, Buehn } \\
\text { ve Montenegro }\end{array}$ & 2007 & Mimic & 37.1 \\
\hline Arjantin & $\begin{array}{c}\text { Schneider, Buehn } \\
\text { ve Montenegro }\end{array}$ & & Mimic & 27.8 \\
\hline Azerbaycan & $\begin{array}{c}\text { Schneider, Buehn } \\
\text { ve Montenegro }\end{array}$ & 2007 & Mimic & 69.6 \\
\hline İsviçre & $\begin{array}{c}\text { Schneider, Buehn } \\
\text { ve Montenegro }\end{array}$ & 2007 & Mimic & 9.1 \\
\hline
\end{tabular}

Kaynak: DPT, 2001, Schneider, 2004 ve Schneider, Buehn ve Montenegro, 2010.

\section{Türkiye'de Kayıtdışı Ekonomi}

Gelişmiş ve gelişmekte olan ülkeler arasındaki refah ve gelişmişlik farkı dünyanın en önemli meselelerinden biridir. Bu farkın büyümesi küresel dengeleri ve istikrarı tehdit etmektedir. Bu farkın azaltılması, fakir ülkelerin sürdürülebilir ve kalıcı bir büyüme trendi yakalamaları ile mümkündür. Dolayısıyla iktisadi büyümenin daha iyi anlaşılmasına yönelik çalışmalar son dönemde ivme kazanmıştır. Bu çalışmalarda büyümeyi açıklayan geleneksel iktisadi modellerin ötesine geçilerek, büyümeyi sağlayacak ve bunu sürekli kılacak politika seçenekleri üzerinde durulmaktadır. Büyüme yanlısı kamu politikaları ele alınırken, refah düzeyi ile verimlilik arasında doğrudan bir ilişki bulunduğu görülmektedir. Gerçekten de dünyanın en müreffeh ülkeleri, verimliliğin en yüksek olduğu ülkelerdir(Deloitte, 2007: 4).

Kayıtdışı ekonominin varlığının ülke ekonomisi ve işgücü piyasası üzerinde önemli etkileri olacağı açıktır. Kayıtdışı ekonomi öncelikle ekonomik istatistiklerin sağlıksız olmasına sebep olmakta ve bu verilere dayanılarak uygulanan politika ve tedbirlerden istenilen sonuçların alınamamasını beraberinde getirmektedir(Arasta, 2006: 46). 
Türkiye'de ekonomik faaliyetlerin önemli bir kısmının kayıtdışı olarak gerçekleştirildiği genel olarak kabul edilmektedir. Türkiye'de kayıtdışı ekonominin ne kadar büyük olduğu konusunda ise kayıtdışılığın tanımı gereği üzerinde uzlaşılan ortak bir rakam bulunmamaktadır. Bu büyüklüğü tahmine yönelik çalışmalar birbirlerinden farklı sonuçlar vermektedirler. Kayıtdışı ekonominin büyüklüğünü ölçmeye yönelik çalışmaların farklı sonuçlar vermesi sadece Türkiye'ye özgü bir durum değildir: kayıtdışını ölçmeye yönelik çalışmalarda kayıtlı ve kayıtdışı ekonominin birbiriyle iç içe geçmesi nedeniyle kesin sonuçlar verecek yöntemler kullanılamamakta ve tahmin metotlarından faydalanılmaktadır(Deloitte, 2007: 6).

Türkiye'de kayıtdışı ekonomiye ilişkin ilk çalışmalar kayıtdışı ekonominin nedenleri ve sonuçları üzerine yoğunlaşmış olmasına karşın daha sonraki çalışmalar kayıt dışı ekonominin çeşitli yöntemler kullanılarak ölçülmesine ve yapısal durumunun incelenmesine yönelik olmuştur. Genel olarak kayıtdışı ekonominin, mal ve hizmet üretimine konu olmasına karşlık ekonominin geleneksel ölçüm yöntemleriyle bütünüyle tespit edilemeyen ve GSMH hesaplamalarına yansımayan alanları kapsadığı kabul edilmektedir. Kayıtdışı ekonomiyi ölçmeye yönelik çalışmalarda kayıtlı ve kayıtdışı ekonominin birbiriyle iç içe geçmesi nedeniyle kesin sonuçlar verecek yöntemler kullanılamamakta ve tahmin metotlarından faydalanılmaktadır. Ülkemizde kayıt dışı ekonomiye yönelik çalışmalar, bu sorunun mali boyutunun gelişmiş ekonomilere kıyasla hayli yüksek olduğunu göstermektedir. Türkiye'de kayıt dışı ekonominin büyüklüğünü belirleyebilmek için çeşitli çalışmalar yapılmıştır. Bu çalışmalar Tablo 4 de özetlenmiştir. Basit parasal oran, vergi yaklaşımı, ekonometrik yaklaşım, nakit oran, işlem hacmi, input-output yöntemi, istihdam yaklaşımı, karma yöntem gibi çeşitli yöntemler kullanılarak aynı ya da farklı yıllar için yapılan çalışmalarda kayıt dışı ekonominin GSMH'ya oranının \%2 ile \%70 arasında değiştiği görülmektedir(GİB, 2009: 4-6).

Tablo 4. Türkiye'de Kayıtdışı Ekonominin Büyüklüğü ile İlgili Tahminler

\begin{tabular}{|c|c|c|c|}
\hline \multirow{2}{*}{ Araştırmacı } & Yıl & Yöntem & $\begin{array}{c}\text { Kayıtdışı } \\
\text { Ekonomi } \\
\text { (GSMH'ya } \\
\text { Oranı \%) }\end{array}$ \\
\hline \multirow{2}{*}{ Ilgın } & 2001 & Basit Parasal Oran & 66,2 \\
\cline { 2 - 4 } & 1993 & Basit Parasal Oran & 55,3 \\
\cline { 2 - 4 } & 1992 & Ekonometrik Oran & 47,2 \\
\hline Altuğ & 1992 & Kayıtdışı İstihdam Yaklaşımı & 35 \\
\hline Derdiyok & 1989 & Vergi Yaklaşımı & 46,9 \\
\hline \multirow{3}{*}{ Temel, Şimşek, } & 1992 & Ekonometrik Yaklaşım & 8,1 \\
\cline { 2 - 4 } Yazıcı & 1992 & İşlem Hacmi & 1,9 \\
\cline { 2 - 4 } & 1991 & Vergi Yaklaşımı(Farklı & $29,9-16,4$ \\
\hline \multirow{2}{*}{ Çetintaş, Vergil } & 1992 & Varsayımlarla) & 23 \\
\cline { 2 - 4 } & 2000 & Ekonometrik Parasal Tahmin & 24,7 \\
\hline Schneider & 2001 & Karma Yöntem & 33,2 \\
\hline \multirow{2}{*}{ Kasnakoğlu } & 1997 & Nakit Oranı & $30-61$ \\
\cline { 2 - 4 } & & Ekonometrik & $9-13$ \\
\cline { 2 - 4 } & & İşlem Hacmi & 31 \\
\hline
\end{tabular}




\begin{tabular}{|c|c|c|c|}
\hline Özsoylu & 1990 & Nakit Oranı & 11,7 \\
\hline \multirow{2}{*}{$\begin{array}{c}\text { Schneider, } \\
\text { Buehn ve }\end{array}$} & 1999 & Mimic & 32.7 \\
\cline { 2 - 4 } Montenegro & 2001 & Mimic & 32.8 \\
\cline { 2 - 4 } & 2005 & Mimic & 30 \\
\cline { 2 - 4 } & 2007 & Mimic & 29.1 \\
\hline
\end{tabular}

Kaynak:GİB,2009 ve Schneider, Buehn ve Montenegro, 2010.

İstatistiki anlamda kayıtdışılığın olumsuz etkileri, kaynağından eksik ve hatalı olarak gelen verilere göre hazırlanan göstergeleri temel alarak oluşturulacak politikaların ve alınacak önlemlerin uygulamada başarısız olması ve istenmeyen sonuçlara yol açması şeklinde dolaylı bir şekilde ortaya çıkmaktadır. Yapılan düzenlemelere uyulmamasından kaynaklanan kayıtdışılığın etkileri ise daha çok doğrudan olumsuz sonuçlar doğurmaktadır. Bir ekonomide ulaşılmaya çalışılan temel amaçlar; kaynak dağılımında etkinlik ve kaynakların verimli kullanılması, yeterli ve sürdürülebilir büyüme, fiyat istikrarı, gelir dağılımında adalet, dış dengenin sağlanması olarak özetlenebilir. Ülkenin refah düzeyi, istihdam ve fiyatlar genel seviyesi ve gelir dağılımı konularındaki iktisadi gerçeklerin doğru saptanamaması şeklinde ortaya çıkan istatistiki kayıtdışılığın, bu sayılan amaçlara ulaşma konusunda etkisi bulunmaktadır. GSMH, istihdam, fiyatlar, gibi temel göstergelerin kayıtdışılık nedeniyle doğru olarak belirlenememesi, etkin ve doğru politikalar ile gerekli önlemlerin alınıp uygulanamamasına, uygulamaların başarısızlığına, kaynakların yanlış yönlendirilmesine ve istenmeyen sonuçların ortaya çıkmasına neden olmaktadır(DPT, 2001: 6-7).

Kayıtdışı ile mücadelede ve kayıtdışını önlemede toplumsal değer yargıları büyük önem taşımaktadır. Yolsuzlukla mücadelede olduğu gibi kayıtdışının doğmasını ve büyümesini engelleyen en önemli faktörlerden biri "peer pressure" olarak adlandırılan çevre baskısıdır. Bu çevre baskısının oluşabilmesi için toplumun ahlaki değerlerinin kayıtdışını dışlaması ve bu dışlamanın da bir toplumsal norm haline gelmesi şarttır. Böyle bir toplumda çevre baskısı kendinden dengeleyici bir rol oynayacak ve kayıtdışının büyümesini engelleyecektir. Buna karşılık bu tip bir toplumsal normun oluşturulamadığı ülkelerde bu kez tam tersine kayıtdışını arttıran bir süreç söz konusudur. Bu tip durumlarda Kayıtdışı adeta kendi başına bir norm haline gelmektedir. Toplumsal değer yargılarının Türkiye'de kayıtdışılığın büyümesini engelleyecek bir şekilde gelişmemesinin, kayıtdışının büyümesine neden olan faaliyetlerin toplum tarafından dışlanmamasının ve hatta bazı durumlarda meşru görülmesinin açıklaması, farklı sosyal dinamikler sonucu oluşan bilincin ne şekilde geliştiği incelenerek yapılabilir. Türkiye'de sosyal bilincin doğru bir şekilde gelişememesinin en önemli nedenlerinden biri kronikleşmiş bir sorun olan kamu yönetiminde şeffaflığın sağlanamaması ve takiben vatandaşlarla devlet arasında bir güven eksikliğinin var olmasıdır. Bu güven eksikliğinden dolayı vatandaşların kafalarında vergi gelirlerinin ne şekilde kullanıldığına dair soru işaretleri oluşmaktadır. Ödenen vergilerin kamusal hizmet olarak geri dönmediğini düşünülmesi vatandaşları vergi kaçırmaya, vergiden kaçınmaya ve benzeri arayışlara ve faaliyetlere yönlendirmektedir(Aslanoğlu ve Yıldız, 2007: 131-132).

Hükümetler tarafından yapılan düzenlemeler, alınan vergiler ve yapılan diğer kesintiler ve bunların nasıl kullanılacağı, toplumun genel çıkarı ve bireysel olduğu kadar sosyal yararları da düşünülerek, ekonominin bütünü için etkin kaynak dağıımını geçekleştirmek amacıyla belirlenmektedir. Kayıtdışı faaliyetlerin genel 
olarak arzulanmayan faaliyetler olduğu, emek yoğun ve gelişmiş olmayan teknolojiler kullanılan alanlarda yoğunlaştığı dikkate alınırsa, kayıtdışı ekonominin kaynak dağıımında etkinliği bozduğu ve kaynakları verimsiz alanlara yönelttiği sonucu çıkmaktadır. Faaliyetlerini kayıtdışı olarak yürütenler, faaliyetlerini kayıtlı olarak yürütenlerin kayıtlı olmaktan dolayı katlandıkları oldukça yüksek ek maliyetlere katlanmadıklarından, haksız rekabet avantajı elde edilmektedir. Bu ekonomideki rekabet yapısını bozmakta, sonuçta rekabetçi piyasanın etkin kaynak tahsisini gerçekleştirme fonksiyonu kaybedilmektedir. Büyük firmalardan kaynaklanan kayıtdışıık dışında, kayıtdışı faaliyetlerin daha çok küçük organizasyonlar ve şirketleşmemiş birimler tarafından gerçekleştiriliyor olması, büyük firmaların da işlerini taşeronlar aracılığıyla veya küçülerek yürütme çabaları, ekonominin merkezilikten uzaklaşmasına yol açmakta, bu durum optimum ölçek büyüklüğünün sağlayacağı verimlilik artışı gibi avantajların elde edilememesi sonucunu doğurmaktadır. Kayıtdışıı̆ın en önemli nedenlerden birisinin de yüksek vergi oranları olduğu düşünülürse, kayıtlı kesimin vergi yükünün artıııması, bu kesim aleyhine olan adaletsizliği daha da artırmaktadır(DPT, 2001: 7).

Maliye Bakanlığı'na göre 2009 yılı itibariyle Türkiye'de ekonominin \%28'i kayıt dışında bulunuyor. Son 8 yıllık dönemde kayıt dışlık sadece Katma Değer Vergisinde 104 milyar liralık ekonomik kayba neden oldu. 2002 ylından 2006 yllına kadar ki dönemde kayıt dışıllkta bir iyileşme görüldü. Ancak dünya ekonomisinde ortaya çıkan krize paralel 2007, 2008 ve 2009 yıllarında kayıt dışılık rakamlarında bir yükselme gözlendi. Red ve iadeler sonrası 2007 yılında \%19'a yükselen kayıt dışıllık oranı, 2008 yllında \%20, 2009 yllında ise \%28 olarak gerçekleşti. Bu da kriz dönemlerinde kayıtdışılığın arttığını göstermektedir. Hesap Uzmanları Kurulu'nun Kayıtdışı Ekonomi Raporuna göre, 2002-2009 döneminde GSYİH 2,72 kat, Vergi ve sübvansiyonlar ise 2,6 kat arttı (Ekonometre, 2012). Friedrich Schneider'in yapmış olduğu ve 31 Avrupa ülkesininin 2003-2010 yılları arasındaki kayıtdışılık durumunu inceleyen çalışmaya göre 2010 ylı itibariyle Türkiye'de kayıtdışından kaynaklanan vergi kaybının Gayri Safi Yurtiçi Hâsıla'ya oranı yaklaşık \%5,7'dir. Bu da 64,8 milyar TL'lik vergi kaybı demektir.

Yasadışı faaliyetler, konusu suç olan ve yasalarla cezalandırılan faaliyetlerdir. Bu faaliyetler sonucu oluşan ekonomik değerler, gelirin kaynaklık ettiği faaliyetin yasadışı olması nedeniyle, suç ekonomisi olarak adlandııımaktadır. Bu doğrultuda suç ekonomisi olarak tanımlanan bu ekonomik büyüklük, yasadışı faaliyetlerden kaynaklanan ekonomiyi tanımlamak anlamında kullanılmaktadır. Ülkemizde suc ekonomisini önlemeye yönelik veya bu konuda düzenleme getiren çeşitli yasalardan oluşan oldukça geniş bir mevzuat bulunmaktadır. Yasadışı mal ve hizmet üretimi sonucunda oluşan kayıtdışı ekonomi, bir başka ifadeyle suç ekonomisi kayıtdışı ekonominin önemli bir alt ayrımıdır. Suç ekonomisinde belirleyici unsur faaliyetlerin yasaların öngördüğü şekilde yapılmaması değil, faaliyetin kendisinin yasaklanmış olmasıdır. Kayıtdışı ekonominin diğer bölümlerinde "gelir"in yasalara aykırı bir şekilde kayıtdışına çıkarılması söz konusu iken, suç ekonomisinde "üretim" yasalara aykırı olarak gerçekleşir. Faaliyet yasadışı olduğundan, yasadışı üretim sonucunda elde edilen gelir de doğası gereği gizlenme eğiliminde olması nedeniyle kayıtdışıdır. Diğer taraftan kayıtlı ekonomi içerisinde, konusu suç olan faaliyetler sonucunda elde edilen iktisadi değerlerin söz konusu olabileceği de bir gerçektir. Bu anlamda kayıtlı ekonomi ile bir geçişkenlik söz konusu olabilmektedir. Ancak nihai amaç bu ekonomiyi kayıt altına almak değil, ortadan kaldırmak olduğundan, mücadeleye 
yönelik önlemler kaçınılmaz olarak bu hususları da içerecektir. Suç ekonomisinin üretim, dağıım, tüketim ve diğer her tür faaliyetlerinin kapsadığı sürecin yasadışı olması, bu kapsamdaki faaliyetlerin genellikle konusunda uzmanlaşmış suç örgütlerince organize edilmesi ve yürütülmesi sonucunu doğurmaktadır(DPT, 2001: 56-57).

\section{Sonuç}

Kayıtdışı ekonomi ülkemiz öznelinde değil tüm dünya için ciddi bir meseledir ve artık yapısal bir sorun haline gelmiştir. Gelir dağııımının düzenli olmadığı Ülkemizde, kayıtdışı faaliyetler milli gelirden bireylerin aldığı payın azalmasına ve zengin ve fakir arasındaki uçurumun daha da artmasına yol açmaktadır. Bu da bireyleri yeniden kayıtdışılığa yöneltmekte ve durum bir kısır döngü haline gelmektedir. Bazen ekonomik sebeplerden bazen de siyasi veya başka sebeplerden kaynaklanan kaynaklı olarak çıkan vergi affı uygulamaları ile, vergisini düzenli bir şekilde ödeyenlerde oluşan cezalandırılma olgusu bu kimseleri de kayıtdışlığa yöneltebilmektedir. Siyasi ve ideolojik yaklaşımlar da kayıtdışılığa meyil eden kişiler ve kurumlar için bir firsat olarak görülmektedir. İktidar olan siyasi parti veya partiler kendilerine oy veren seçmenlerin ve de oluşumun taban kesiminin beklentilerini dikkate alarak bir dizi faaliyetlere ve düzenlemelere girişmekte ve diğer kesimleri görmezden gelmektedirler. Görmezden gelinen kesimler ise bir takım finansal sıkıntılarla karşılaşabilmekte ve bu dışlanmışlığın vermiş olduğu bu saikle kayıtdışı faaliyetlere yönelebilmektedirler.

İşsizlik ve kayıtdışı istihdam Türkiye Ekonomisi için gündemini koruyan ciddi bir sorundur ve bu sorun komşu ülke Suriye'den gelen göçmenlerin de etkisiyle ciddi artışlar göstermiştir. İşsizlikle mücadele edilirken kayıtı istihdamı da teşvik eden düzenlemelerin bir an önce hayata geçirilmesi ve uygulanması gerekmektedir. Kayıt altına alınmayan ekonomik faaliyetlerin kayıt altına alınması ve illegal veya yasadışı ekonomik faaliyetlerin önlenmesi gerekmektedir. Kamu gelirlerinin çoğunu vergi gelirleri oluşturduğu için vergi ve sosyal güvenlik sistemindeki aksaklıkları giderici bir vergi ve sosyal güvenlik reformu da mevcut sorunların çözümüne katkı sağlayacaktır. Yüksek vergi oranlarıla birlikte vergi bilincinin tam yerleşememiş olması hem kişileri hem de kurumları kayıtdışı faaliyetlere yöneltmekte ve kamu gelirlerini azaltıı etki yapmaktadır. Onun için devletin vergi oranlarını adil ve dengeli bir şekilde düzenlemesi gerekmektedir.

Vatandaşlar devletin kendilerine sunmuş olduğu hizmetlerin yetersiz olduğunu düşünmekte ve herkes yapıyorsa ben neden yapmayayım bilinciyle hareket ederek yapmış olduğu veya yapılan kayıtdışı faaliyetlerin makul olduğuna inanmaktadır. Piyasalara kayıtdışı olarak arz edilen ürünlerin fiyatlarının, yasal olarak piyasaya arz edilen ürünlere göre düşük olması, tasarruflarda artı̧̧a ve sermaye birikimine neden olmasına rağmen uzun vadede sadece ekonomiyi değil bir bütün olarak ülkeyi de çıkmaza sürükleyeceğinden, kayıtdışı ekonominin pozitif etkilerinin mücadeleyi sekteye uğratmaması için politika seçiminde hassas davranııması gerekmektedir. Uzun yıllar yüksek enflasyon oranlarıyla ve yüksek ve adil olmayan vergi oranlarıyla yaşamış olan insanımızın mücadele bilincini benimsemesi ve buradan hareketle kayıtlı faaliyetlerin özendirilmesi kolay olmayacağı gerçeği de politika seçimini yapılırken olayın sosyal, siyasal, psikolojik ve teknolojik boyutlarının da göz önünde bulundurularak yapılmasını zorunlu kılmaktadır. Seçilecek politikalar 
kısa vadeli değil de uzun vadeli olarak belirlenmeli ve uygulanan ekonomi politikalarına entegre edilmeli ve sürdürülebilir olmalıdır. Bir diğer önemli faktör olan suçların özellikle de ekonomik suçların önlenebilmesi için ise ekonomik özgürlüklerin arttırılması gerekmektedir. Bu yapıldığı takdirde suç eğilimlerini hafifletici etkiler ortaya çıkacaktır. Yaşam koşullarının iyileştirilmesiyle beraber kaynakların harekete geçirilerek yoksulluğun azaltılması, refah artışının sağlanması ve bunun sürdürülebilmesi için gelecek nesiller için de kaygı verici olan kayıtdışı ekonominin kayıt altına alınması bir zorunluluk olarak karşımıza çıkmaktadır. Tüm bunlar yapılırken siyasi iradenin kararlı bir tutum sergilemesi ve siyasi hesaplar yapmaması güvenilirliği ve inandırıcı arttıracağı için olmazsa olmaz koşuldur.

\section{Kaynakça}

Akalın, G., ve Kesikoğlu, F.(2007). Türkiye'de Kayıtdışı Ekonomi ve Büyüme İlişkisi. ZKÜ Sosyal Bilimler Dergisi, Cilt 3, Sayı 5, 2007, ss. 71-87.

Aktan, C., C.(1999). Ağır Vergi Yükü ve Yer altı Ekonomisi. Vergi Sorunları Dergisi, Şubat-1999, Sayı.125, s.51-55.

Anno, R., D.(2003). Estimating The Shadow Economy in Italy: a Structural Equation a

Approach. For 44 Riunione Scientifica Annuale SIE, JEL Classification: O17, C39, H26.

Altuğ, O.(1999). Kayıtdışı Ekonominin Boyutları. Erciyes Üniversitesi İİBF Dergisi, Sayı 15.

Arasta(2006). Kayıtdışı Ekonomi Nereye Kadar? Sayı:29, Mart-Nisan 2006.

Aslanoğlu, S., ve Yıldız, S.(2007). Türkiye'de Kayıtdışı Ekonomi Olgusu, Bu Olguyu Azaltmaya Yönelik Çözüm Arayışları ve Bir Öneri: Rasyo Analizi Yoluyla Etkin Bir İnceleme Sisteminin Oluşturulması. Sosyo Ekonomi Dergisi, Yıl.3, Sayı.6, s. 127-146.

Baldemir, E., Gökalp, F. Ve Avcı, M. (2010). Türkiye'de Kayıtdışı Ekonominin Mimic Model ile Tahminlenmesi. Ekonometri Derneği.

Bhattacharyya, D., K.(1999). On the Economic Rationale of Estimating the Hidden Economy. The Economic Journal, Vol. 109, No. 456.

Candan, M.(2007). Kayıtdışı İstihdam, Yabancı Kaçak İşçi İstihdamı ve Toplumumuz Üzerindeki Sosyo-Ekonomik Etkileri. Calışma ve Sosyal Güvenlik Bakanlığı Türkiye İş Kurumu Genel Müdürlüğü Uzmanlık Tezi.

Choi, P., J., ve Marcel T.(2005). Corruption and the Shadow Economy. International Economic Review, Vol. 46, No. 3 (Aug., 2005), pp. 817-836. http://www.jstor.org/stable/3663494 Erişim Tarihi: 23.12.2011.

Çetintaş, H., ve Vergil H.(2003). Türkiye'de Kayıtdışı Ekonominin Tahmini. Doğuş Universitesi Dergisi, 4(1) 2003, 15-30.

Deloitte.(2007). Kayıtdışı Ekonomi Türkiye Serüveni. http://www.deloitte.com Erişim Tarihi: 16.12.2012.

DPT(2001). Kayıtdışı Ekonomi Özel İhtisas Komisyonu Raporu. Sekizinci Beş Yıllık Kalkınma Planı.

Eilat, Y., ve Zinnes, C.(2000). The Evolution of the Shadow Economy in Transition Countries: Consequences for Economic Growth and Donor Assistance. 
www.ekonometre.net/haber/ekonominin/yuzde/28i/kayit-diși Erişim Tarihi: 09.01.2012.

Feige, E., L.(1990). Defining and Estimating Underground and Informal Economies: The New Institional Economics Approach. World Development Vol 18, No. 7; July 1990.

Frey, B.,S., ve Schneider, F.(2000). Informal and Underground Economy. Forthcoming in Orley Ashenfelter: International Encyclopedia of Social and Behavioral Science, Bd. 12 Economics, Amsterdam: Elsevier Science Publishing Company, 2000.

GíB.(2009). Kayıtdışı Ekonomiyle Mücadele Stratejisi Eylem Planı(2008-2010). Gelir İdaresi Başkanliğı, Strateji Geliştirme Daire Başkanlığı, Yayın No:87.

Giles, D., E., A.(1999). Measuring the Hidden Economy: Implications for Econometric Modelling. The Economic Journal, 109(June).

Ilgın, Y.(2002). Kayıtdışı Ekonomiyi Tahmin Yöntemleri ve Türkiye'de Durum. Planlama Dergisi. Devlet Planlama Teşkilatı. http://ekutup.dpt.gov.tr/planlama/42nciyil/ilginy/kayitdis.pdf Erişim Tarihi: 28.11.2011.

Işık, N., ve Acar M.(2003). Kayıtdışı Ekonomi: Ölçme Yöntemleri, Boyutları, Yarar ve Zararları Üzerine Bir Değerlendirme. Erciyes Üniversitesi İktisadi ve İdari Bilimler Fakültesi Dergisi, Sayı:21, Temmuz-Aralık 2003, ss. 117-136.

Losby, J., L., Else, J., F., Kingslow M., E., ve diğerleri(2002). Informal Economy Literature Review, www.ised.org Erişim Tarihi: 22.03.2012.

Öğünç, F., ve Yılmaz, G.(2000). Estimating The Underground Economy in Turkey. The Central Bank of The Republic of Turkey, Discussion Paper, September, 2000.

Schneider, F., ve Enste, D., H.(2000). Shadow Economies: Size, Causes and Consequences. Journal of Economic Literature Vol. XXXVIII (Mart 2000) ss. 77-114.

Schneider, F.(2004). The Size of the Shadow Economies of 145 Countries all over the World: First Results over the Period 1999 to 2003. IZA DP No. 1431 Discussion Paper No. 1431 http://ssrn.com/abstract=636661 Erişim Tarihi: 20.09.2013.

Schneider, F., Buehn, A., ve Montenegro, E.(2010). New Estimates for the Shadow Economies all over the World. International Economic Journal, Vol.24, No.4, 443-461.

Tepav.(2006). Yolsuzlukla Mücadele TBMM Raporu "Bir Olgu Olarak Yolsuzluk: Nedenler, Etkiler, Çözüm Önerileri. Tepav Yolsuzlukla Mücadele Kitapları-I.

Şimşek, A., Temel A., ve Yazıcı K.(1994). Kayıtdışı Ekonomi Tanımı, Tespit Yöntemleri ve Türk Ekonomisindeki Büyüklügü. İktisat İşletme ve Finans, Kasım 1994, Sayı 104.

Us, V.(2004). Kayıtdışı Ekonomi Tahmini Yöntem Önerisi: Türkiye Örneği. Türkiye Ekonomi Kurumu Tartışma Metni 2004/17, http://www.tek.org.tr Erişim Tarihi: 12.05.2012.

Yurdakul, F.(2008). Türkiye'de Kayıtdışı Ekonomi: Bir Model Denemesi. Ankara Üniversitesi SBF Dergisi, 63-4. 